UDC 002.8(001.378):37

DOI https://doi.org/10.32840/1992-5786.2020.70-3.34

L. L. Petliovana

Ph.D., Associate Professor, Associate Professor of the Department of Foreign Languages of Khmelnytskyi National University

S. V. Sukhovetska

Senior Lecturer of the Department of Foreign Languages of Zhytomyr Polytechnic State University

V. A. Shadura

Senior Lecturer of the Department of Foreign Languages of Zhytomyr Polytechnic State University

\title{
TEACHING ENGLISH AT HIGHER SCHOOLS BY MEANS OF E-PLATFORMS UNDER CONDITIONS OF QUARANTINE
}

This article covers the problem of teaching English at higher schools by means of e-platforms under conditions of quarantine. Schools and universities across the globe have already closed in the wake of the coronavirus pandemic. As a result, teachers are suddenly faced with the challenge of how to continue their students' education. While this might seem a daunting task, there are several ways teachers can utilize the technology and resources already available to support online learning and ensure students still receive a quality education. It's important to note that there is no one size which fits all when it comes to learning. Different groups have different priorities and the resources that should be used are context-dependent. However, teachers should take some comfort in the fact that there are hundreds of online resources to guide them as to how to teach online. Designing effective distance learning programs requires planning and targeted professional development. Teachers who did not expect to teach online were caught understandably unprepared in the final leg of the academic year.

The present article focuses on such e-platforms as Moodle, which has been used at our universities since 2008 and has a great importance in teaching English at an appropriate level, Zoom and Skype, which are currently being used in order to provide interaction and communicative activities representative of specific professional or academic environments. The convenience of learning from a distance from the comfort of one's home or from any location where one happens to be and having access to teachers and native speakers around the world are some reasons for the popularity of these online resources for language learning. Other reasons might be the mostly free service, availability for major computer platforms, the reliability of the service, the relatively good quality of audio and video if used with a broadband connection, and also its ease of use. Moodle provides a collaborative medium, a place where we can all meet and read and write. Zoom allows you to connect with students using an interactive video conference platform. Skype also allows screen sharing, which means that the teacher or students can show Word documents, slide presentations, or websites on their screen to the other participants in a Skype session or explain something.

Key words: e-platforms, distance learning, teaching English, interaction and communicative activities, Moodle, Zoom, Skype.

Setting the problem. With the spread of the COVID-19, countries are implementing emergency plans to slow down and limit the spread of the virus - and prepare for a possible longer term disruption of school and university attendance. Every week of school closure will imply a massive loss in the development of human capital with significant long-term economic and social implications. While this is a strong stress test for education systems, this is also an opportunity to develop alternative education opportunities.

We are in a state of emergency and must react with different ways of working, shopping, learning and communicating. Online shopping and social networks are not new to us, nor is distance learning. However, COVID-19 is reviving the need to explore online teaching and learning opportunities. The education sector is responding to quarantine with a sudden shift to online learning. Nonetheless, online teaching requires careful thinking about how learners and teachers are equipped for the shift and serious consideration about whether the teaching style is still effective when taken from the classroom and transposed to technological devices. Moreover, inequalities are exacerbated when it comes to access to technology and to digital devices. Many learners suffer a form of digital inequality whereby they lack the connections and devices to learn remotely. 
Foreign language teachers began to integrate electronic communication into language teaching in the late 1980s guided by the desire to provide authentic communication, to make students recognize the importance of cultural exchange, and the desire to teach new skills. Later experience has shown that computer-assisted classroom discussions are great equalizers of student participation. Motivated by such experiences and the intention to motivate our students, we decided to introduce so called blended (hybrid) teaching model in the course of English for Special Purposes (ESP), encouraged by the Teaching Strategies accepted by Khmelnytskyi National University in 2008 recommending the usage of ICT in the teaching activities at the tertiary level.

Analysis of recent research and publications. The use of technology in every field of life has become a universal slogan. Despite its ambivalent effect on academic teaching and learning, the incorporation and exploitation of technology is at its highest demand level around globe. It seems to be a race against time. The general consensus among teachers and students is, the more technological your educational and academic environment, the more successful you are in an ever changing world [6, p. 3]. With this given scenario, it is not at all surprising that Ukrainian students also use these digital platforms excessively. For them, the use of these platforms comes in various shapes and forms, from IMS and emails to social networking involving blogs, microblogs, wikis, podcasts, videos and RSS feeds.

The popularity of social networking sites (SNS) such as Facebook, WhatsApp, Twitter, YouTube, MySpace and Instagram has been taking the attention and the focus of young Ukrainians by storm [1, p. 207]. A typical answer to a question such as "what is your favourite pastime?" is "my social space!" which is enough to explain the passionate level of interest that these young individuals have for their personal presence and social preferences. The students spend a lot of their precious time on these social networking sites (SNS) which can also be used more effectively to achieving their academic goals.

Many studies undertaken by distinguished researchers have revealed that Facebook is the most popular social networking site among students [3; 7; 11]. It has been reported that it can have a significant impact on a students' performance [7, p. 148]. It offers educational value to both students and teachers. To students it may foster positive relationships among peers of similar ages and interests [13, p. 619], transfer of knowledge [7, p. 150], quality of learning $[9$, p. 86], cognitive and social competencies, interpersonal intelligence and critical thought, and consolidate self-confidence and self-esteem [2, p. 193]. From the teachers' perspective, we can see that Facebook contributes to the credibility of teachers engaged in contemporary student culture, maintains pre-established relationships $[2 ; 10 ; 13]$, is a means to provide constructive educational outcomes [10, p. 233], offers a differential pedagogy, integrates diagnostic formative assessment $[9 ; 11]$, accounts for human behaviour by using Facebook in learning activities, creates novel educational settings on a social network [11, p. 163], promotes course related materials and discussions, promotes the student as an interacting partner and develops knowledge and skills in order to perform efficient didactic activities [4, p. 21].

A number of researchers have suggested that electronic communication differs linguistically from both traditional written and spoken discourse $[4 ; 5 ; 8]$ showing that electronic discussion is similar to written texts in terms of language complexity, and that it could serve as an important bridge for transfer of communication skills from the written to spoken domain. No study has been done yet with the students of ESP to find out whether they might be more successful in learning English in classes supported by the advantages of ICT technology. This research was carried at the tertiary level, with the students who already participated in that kind of teaching and learning model - through Moodle platform, Zoom and Skype.

The purpose of the article. The paper has the aim to present how certain online resources and tools engaged in the teaching process in ET courses can act under conditions of quarantine. The employment of these resources and tools is expected to spur students' creativity and engage higher-order thinking skills while at the same time focuses on the target communicative events.

Presenting the main material. In the context of necessary closures, different forms of online education and education resources should be mobilised. We have chosen some of them: Moodle, where we have had fully-developed courses in different subjects since 2008, Zoom for video communication and Skype.

There are a lot of merits that could be mentioned when speaking about using Moodle in teaching and learning English as a foreign language. Moodle provides a collaborative medium, a place where we can all meet and read and write. As a modular objectoriented dynamic learning environment, Moodle provides many very useful modules for language learning. Besides standard modules, there are more and more modules under developing and will become a standard module when they are proved to be useful and stable.

The basic modules provided by Moodle may be grouped as follows:

1. The "People" Box: Participants, Profile, Activity reports. 2. Administering Your Class: Settings, Teachers, Students, Backup, Restore, Scales, Grades, Logs, Files, Help, Teacher Forum. 3. Adding 
Content: (a) Adding a Resource: Compose a text page, Link to a file or web site, Display a directory, Insert a label (b) Adding an Activity: Assignment, Chat, Choice, Forum, Glossary, Hot Potatoes Quiz, Journal, Lesson, Quiz, SCROM, Survey, Wiki, Workshop [12, p. 18].

After creating participants' box, constituting a profile of our course and setting the basic principle of administering the class, a lot of attention has been paid to the creation of activities. Having in mind the fact that it was the first time that this kind of teaching and learning was offered to our students, we decided to choose easier approach. The role of ESP practitioners as teachers, course designers and material providers, collaborators, researchers and evaluators was focused on the efforts to meet specific needs of learners, making use of the underlying methodology and activities of the discipline it serves and being centred on the language (grammar, lexis, register), skills, discourse and genres appropriate to these activities. Possibility to add links to a file or web site offering new fresh material was of the utmost importance for students, which were then used as authentic learning materials, modified or unmodified in form for the simulation of communicative tasks, preparation of papers, reading, note taking, and writing, but were not enough to make the students respond to the given tasks.

Here we illustrate the contents of the course, where students can find all necessary materials to study and achieve final results (Fig. 1).

The Moodle activity 'Forum' was also very helpful, especially in triggering the communication among students. The forum called "To Learn English" was opened within the scope of our ESP-class on Moodle for the students to communicate about any topic they found interesting or intriguing, but in English. They did not start chatting with each other very enthusiastically in the beginning. After some encouragement by the teacher, the students were instructed to talk freely about any topic they want to discuss. The teacher would not participate in their discussions, just monitor the participation. Gradually, the discussion started to develop. Those who rejected totally any kind of participation in the beginning joined the discussion, intrigued by other student's opinions and willing to react. It seemed that not having to express themselves in public, i.e. in the class when everyone is listening and looking at them, helped a lot of students to forget about their fears and start using their English, no matter how good or bad it was.

One of the most successful activities done with the students was glossary. It is a place allowing students to create and maintain a list of definitions - like a dictionary. Good dictionaries of technical and economic terms are not always available, especially in disciplines like geodesy, economic cybernetics, demography and others. Working on the creation of such a dictionary can be very inspiring, because the students know they are doing a useful job, leaving something behind that others might use sometimes in the future. At the same time, it is a very good research task for students who learn foreign languages, because they are exposed a lot to authentic sources, they practice their understanding of new material and learn how to make definitions of their own in a foreign language.

In Figure 2 we show the main activities, which students have to do on a certain topic.

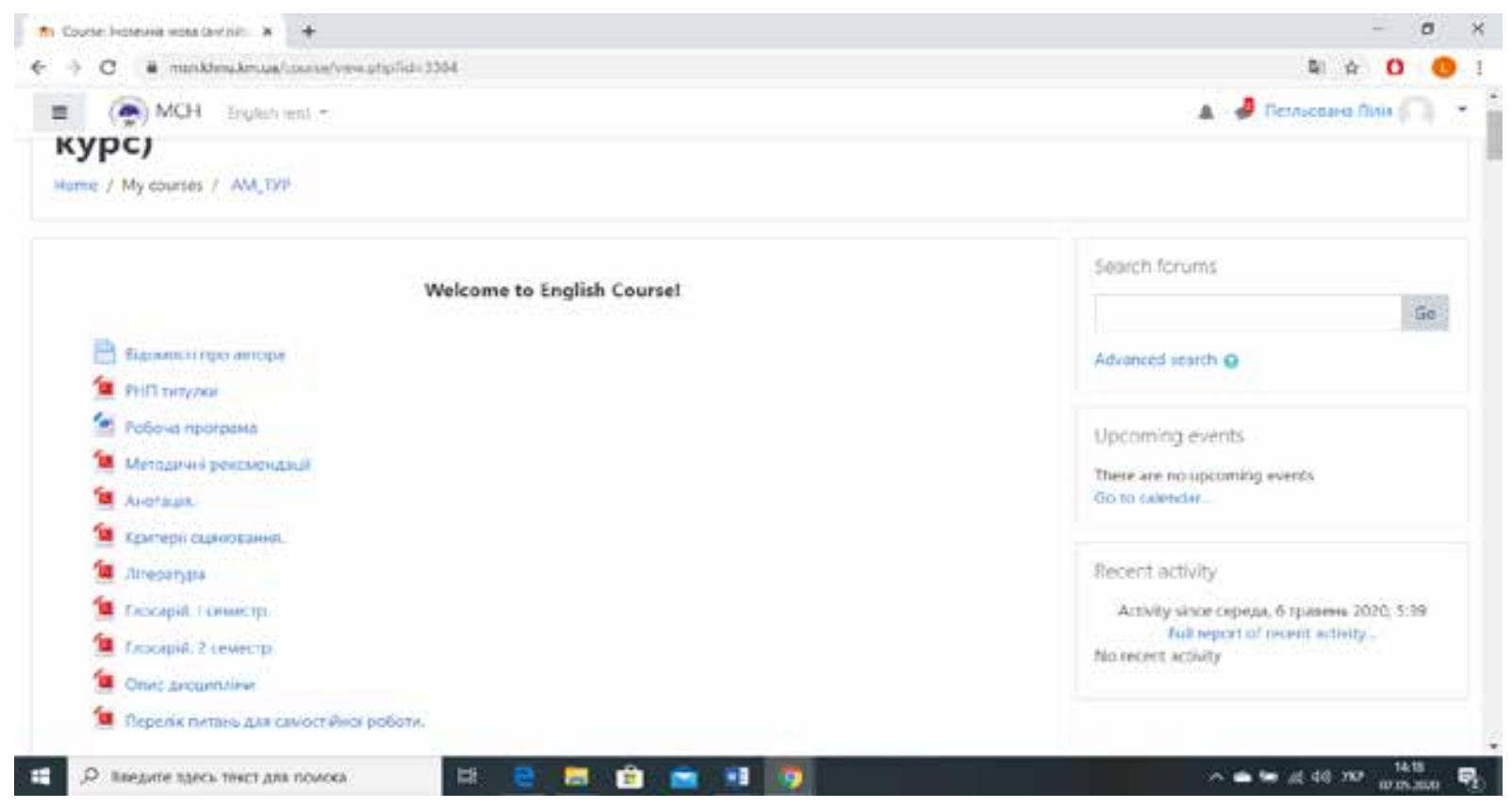

Fig. 1. The contents of the course 


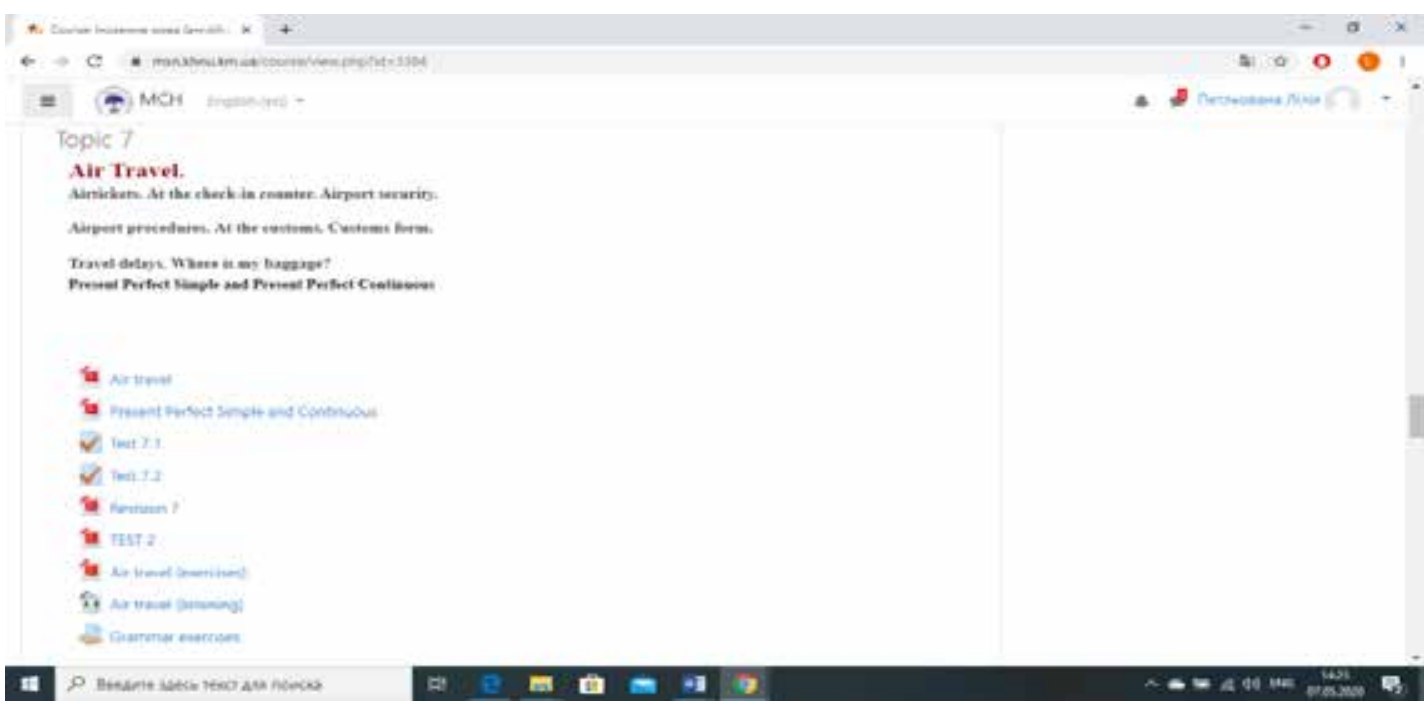

Fig. 2. The activities, which students have to do on the topic "Air Travel"

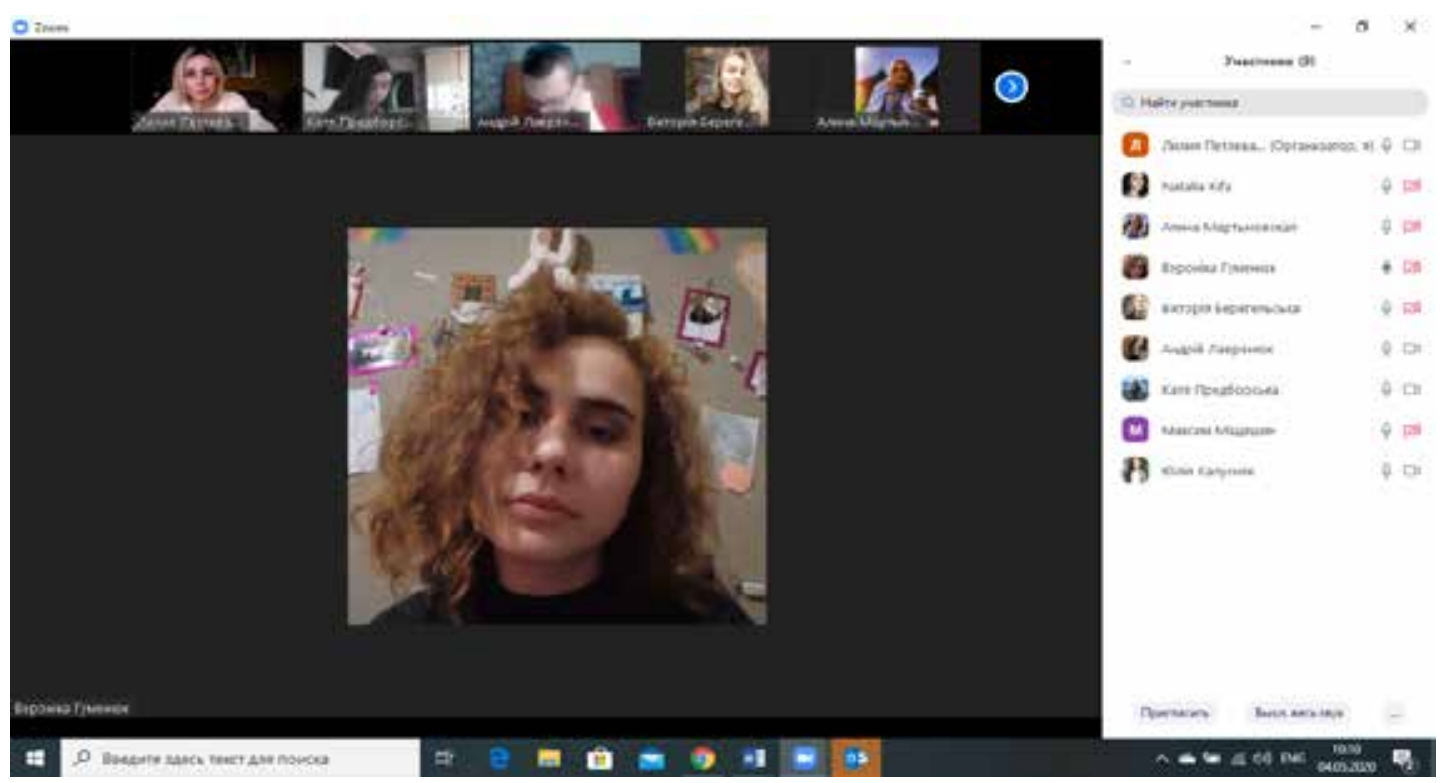

Fig. 3. Online conference in Zoom

There are many kinds of quizzes available on Moodle. Our students participated in multiple choice, and true / false quizzes. They were not meant to evaluate their knowledge, but to help them practice and check for themselves how successful they were in certain activities - mostly for selfevaluation after reading or listening of the authentic material. Due to its multi-media possibilities, there was also audiovisual material offered on Moodle for the students to watch and listen. Multiple-choice quiz helped them to check their understanding. Moodle quizzes do not offer solutions to questions, but inform the participants whether their answers are correct or not. They have to look for the right answers themselves, which means repeating, watching and listening, or reading again.
Zoom allows you to connect with students using an interactive video conference platform. The free version offers unlimited 1 to 1 meetings or group meetings which are limited to a 40-minute duration. Zoom's features like screen sharing, system sound sharing, a whiteboard, screen annotation and meeting recording are ideal for an online classroom. The meetings I have with my class throughout the week focus much less on instruction and instead on using that time to help my students collaborate with peers, continue to socialize, and find ways to connect while remaining socially distant. Figure 3 illustrates the online conference with students.

Skype / online conferencing tools. There are many online voice-over internet protocol (VoIP) services that allow users to make telephone or video calls 
and conduct group conferences using their computer, and Skype is one of the better known and is widely used. In its basic form, the application is freely downloadable and calls made between computers are without charge. Audio and video conferences can be made between participants, however, free video calls are restricted to two participants. The new version of Skype also allows screen sharing, which means that the teacher or students can show Word documents, slide presentations, or websites on their screen to the other participants in a Skype session, to talk about them or explain something.

There is also a special social media language course and materials integrating Skype called English Out There (http://englishoutthere.com/), which can be used by online teachers or as self-study material by learners. Other teachers invite guest speakers via Skype into their classrooms thus breaking down distance barriers. Skype is also used for tandem language learning either on a one-to-one basis or arranged by teachers for whole classes to bring them together with classes in other countries or regions in order to practise the target languages. The convenience of learning from a distance from the comfort of one's home or from any location where one happens to be, in the case of frequent travellers, and having access to teachers and native speakers around the world are some reasons for the popularity of Skype for language learning. Other reasons might be the mostly free service, availability for major computer platforms, the reliability of the service, the relatively good quality of audio and video if used with a broadband connection, and also its ease of use. Many language learners are also already familiar with the tool from their professional work and use it to communicate with colleagues or business partners. [14; 15].

However, just because a particular technology is widely used does not mean it will automatically enhance language learning. Skype, like any other technology, is just a tool, and it needs to be used in a pedagogically sound way to have a value for language learning.

Conclusions and suggestions. The results and statistical analyses of this research have led to the conclusion that students can use social networking sites actively and effectively for collaborative academic learning and development, especially under conditions of quarantine. Also, they find it easier to provide their feedback on the learning process and teaching methodology in a timely, productive and professional manner. Such experiences allow them to interact with their peers and teachers with a greater interest and response. Moreover, students also utilize their smart devices more constructively to enhance and enrich their academic knowledge. Finally, students find it easier to interpret the technical aspects of ESP and its profound relevance and significance in relation to their chosen field of study. Above all, the Ukrainian students learned to respect and appreciate other people's opinions in an unbiased and objective manner when it comes to professional related issues.

Future research requires further exploring the role of the instructor in the use of Moodle and other e-platforms, because the critical role of the teacher cannot be ignored at any stage of experimentation

\section{References:}

1. Askool, S.S. (2013). The Use of Social Media in Arab Countries: A Case of Saudi Arabia. In Web Information Systems and Technologies (pp. 201-219), Springer Berlin Heidelberg.

2. Bosch, T.E. (2009). Using online social networking for teaching and learning; Facebook use at the university of Cape Town. Communication: South African Journal for Communication Theory and Research, 35(2), 185-200.

3. Cheung, C.M., Chiu, P.Y., \& Lee, M.K. (2011). Online social networks: Why do students use Facebook? Computers in Human Behavior, 27(4), 1337-1343.

4. Chun, D., 1994. Using computer networking to facilitate the acquisition of interactive competence. System 22, pp. 17-31.

5. Ferrara, K., Brunner, H., Whittemore, G., 1991. Interactive written discourse as an emergent register. Written Communication 8(1), pp. 8-34.

6. Gulek, J., \& Demirtas, H. (2005). Learning with technology: The impact of laptop use on student achievement. Journal of Technology, Learning, and Assessment, 3(2), 3-6.

7. Madge, C., Meek, J., Wellens, J., \& Hooley, T. (2009). Facebook, social integration and informal learning at university: "It is more for socializing and talking to friends about work than for actually doing work". Learning, Media and Technology, 34(2), 141-155.

8. Murray, D., 1998. Computer-mediated Communication: Implications for ESP. English for Specific Purposes 7, pp. 3-18.

9. Pasek, J. \& Hargittai, E. (2009, May 4). Facebook and academic performance: Reconciling a media sensation with data. First Monday, 14(5)

10.Pempek, T.A., Yermolayeva, Y.A., \& Calvert, S.L. (2009). College students' social networking experiences on Facebook. Journal of Applied Developmental Psychology, 30(3), 227-238.

11. Selwyn, N. (2009). Faceworking: exploring students' education-related use of Facebook. Learning, Media and Technology, 34(2), 157-174.

12. Warschauer, M., 1996. Comapring Face-to-Face and Electronic Discussion in Second Language Classroom. CALICO Journal, 13 (2), pp. 7-26.

13. West, A., Lewis, J., \& Currie, P. (2009). "Students Facebook "Friends": Public and private spheres. Journal of Youth Studies, 12(6), 615-627.

14. How togetstarted as an onlineteacher of English. URL: https://www.britishcouncil.org/voices-magazine/howget-started-as-online-teacher-english.

15. Resources for Teaching and Learning During This Period of Social Distancing. URL: https://www.kqed. org/mindshift/55521/resources-for-teaching-andlearning-during-this-period-of-social-distancing. 
Петльована Л. Л., Суховецька С. В., Шадура В. А. Навчання англійської мови у ЗВо засобами
е-платформ в умовах карантину
Ця стаття висвітлює проблему викладання англійської мови у вищих школах за допомогою елек-

Ця стаття висвітлює проблему викладання англійської мови у вищих школах за допомогою елекпандемії коронавірусу. Як результат, викладачі несподівано стикаються з проблемою, як продовжити навчання своїх учнів. Хоча це може здатися складним завданням, $є$ декілька способів, як вчителі можуть використовувати вже наявні технології та ресурси, щоб підтримати навчання в Інтернеті та забезпечити, щоб студенти все-таки отримували якісну освіту. Важливо зауважити, що немає жодного розміру, який би підходив усім під час навчання. У різних груп різні пріоритети, а ресурси, які слід використовувати, залежать від контексту. Однак викладачам слід потішитись тим, що є сотні інтернет-ресурсів, які підказують, як навчати в Інтернеті. Розробка ефективних програм дистанційного навчання вимагає планування та цілеспрямованого профресійного розвитку.

Ця стаття зосереджена на таких електронних платформах, як Moodle, яка використовується в наших університетах з 2008 року і має велике значення для викладання англійської мови на відповідному рівні, Zоom та Skyре, які зараз використовуються для забезпечення взаємодії та комунікації. Зручність навчання на відстані, можливість здійснювати процес з будь-якого місця перебування, доступ до викладачів та носіїв мови у всьому світі - це чинники, які зумовлюють популярність цих інтернет-ресурсів для вивчення мов. Іншими причинами можуть бути переважно безкоштовний сервіс, доступність для основних комп'ютерних платформ, надійність сервісу, відносно хороша якість аудіо та відео, якщо вони використовуються з широкосмуговим з'єднанням, а також простота використання. Moodle - це середовище для співпраці, місце, де ми можемо всі зустрічатися, читати та писати. Zоот дозволяє спілкуватися зі студентами за допомогою інтерактивної платформи відеоконференцій. Skуре також дозволяє обмінюватися екраном, викладач або студенти можуть показувати документи Word, слайд-презентації тощо.

Ключові слова: е-платформи, дистанційне навчання, викладання англійської мови, взаємодія та комунікативна діяльність, Moodle, Zoom, Skype. 